\title{
Városi talajok nehézfém vizsgálatai a nyugat-dunántúli régióban (Esettanulmány)
}

\author{
HORVÁTH Adrienn és BiDLÓ András \\ Nyugat-magyarországi Egyetem, Erdőmérnöki Kar, Termőhelyismerettani \\ Intézeti Tanszék, Sopron
}

\section{Bevezetés}

Az urbanizáció jelentős változásokat idéz elő a városi területek talajaiban, ahol a mesterséges folyamatok túlsúlyba kerülnek. A városokban a levegö-, víz- és talajszennyezö anyagok bekerülve a környezeti rendszerekbe hosszútávon fejtik ki egészségkárosító hatásukat. Míg a szennyező anyagok eloszlanak, addig a talaj pufferkapacitásának függvényében - képes ellenállni a terhelésnek, de bizonyos talajtulajdonságok esetén akkumulálja a szennyezőket. A talajszennyező anyagok által okozott változások a legtöbb esetben visszafordíthatlanok, mert a terhelés megszüntetésére - például egy folyamatosan nagy forgalmat bonyolító út esetében - nincs lehetőség.

Jelen kutatás elsődleges célja, hogy bemutassa Sopron és Szombathely városi talajainak állapotát az elvégzett fizikai-, kémiai- és nehézfémvizsgálatok $(\mathrm{Co}, \mathrm{Cu}, \mathrm{Ni}$, $\mathrm{Pb}, \mathrm{Zn}$ ) eredményei alapján. Ezekben a városokban ilyen jellegủ átfogó vizsgálat még nem készült, pedig a növekvő népesség, az infrastruktúra és ezek hatásai már láthatóan nagy szerepet játszanak a városi területeken valaha létezett természetes talajok átminősülésében, eltünésében.

Másodlagos célunk pedig a kimutatható kapcsolatok keresése volt az egyes vizsgált rétegek illetve a talajállapot és a területhasználat között. Eredményeink alapján a lokális problémák könnyebben behatárolhatók, lehetséges okaik feltárása egyszerübb.

Ma már viszonylag sok kutatás, tanulmány foglalkozik a városok bolygatott talajainak az ismertetésével. Az 1970-es évektől német és amerikai kutatók kezdték vizsgálni az antropogén városi talajokat. Általában városi talajok közé sorolják mindazon városi vagy külvárosi talajokat, amelyek felső $50 \mathrm{~cm}$ vastag szintje nem mezögazdasági, de az emberi tevékenység következményeképpen zavart, degradált vagy átkevert jelleget ölt (BOCKHEIM, 1974). A városi talajok rétege változó vastagságú és általában már 40-50 cm-es mélység alatt természetes eredeti talajokon helyezkednek el.

Postai cím: HORVÁTH ADRIENN, NYME Erdőmérnöki Kar, Termőhelyismerettani Intézeti Tanszék, 9400 Sopron, Bajcsy-Zs. u. 4.E-mail.: hadri@emk.nyme.hu. 
Antropogén talajról (BILLWITZ \& BREUSTE, 1980) akkor beszélhetünk, ha a természetes hatásoknál erőteljesebb mesterséges folyamatok kerülnek túlsúlyba és a talajok felépítése megváltozik (RUNGE, 1975). BILLWITZ és BREUSTE (1980) szerint a városi területek tipikus jellemzője a különböző anyagokból (pl.: fa, papír, üveg, müanyag, aszfalt, szerves hulladék stb.) álló néhány méter vastag antropogén felhalmozódás. Felhalmozódásuk mellett ezek a mesterséges anyagok keveredhetnek természetes anyagokkal is (HILLER \& MEUSER, 1998).

Az első átfogó gyüjteményt a BULLOCK és GREGORY szerkesztőpáros jelentette meg 1991-ben az Egyesült Királyságban végzett urbán talajvizsgálatokról. A tanulmányban elsősorban a városi talajok képződésével és fejlődésével, valamint a talajok horizontális és vertikális változékonyságának vizsgálatával foglalkoztak. Ebben a könyvben ír THORTON (1991) több más az Pb, Zn és a Cd kutatásával kapcsolatos eredményeiről; Az Egyesült Királyság 53 városának 100-100 háztartásában történt vizsgálatainak eredményeiből kiderült, hogy a házi pornak érzékelhetően magasabb az Pb-, Cd-, Zn- és Cu-koncentrációja, mint a házkörüli konyhakertek talajainak.

BURGHARDT (1994) szerint a városi talajok talajfejlődési folyamatai, indikátorai még nem eléggé ismertek, így fejlődésük irányát nehéz megjósolni. Ennek oka, hogy nemcsak természetes faktoroktól, hanem a szociális és gazdasági folyamatoktól is függenek. Mivel az urbán talajok alkáli fémekben gazdagabbak, így magasabb a pH-értékük. Ennek egyik oka a városi építkezési hulladékok talajba kerülése, a másik pedig a jégmentesítés során kijuttatott $\mathrm{NaCl}$ és $\mathrm{CaCl}_{2}$.

BLuME és HellRIEGEL (1981) Berlin Cd-tartalmú talajainak szennyezettségét vizsgálta. A terület pleisztocén eredetủ üledékkel fedett, aminek természetes háttérkoncentrációja $10 \mathrm{mg} \mathrm{Pb} \cdot \mathrm{kg}^{-1}$ és $0,1 \mathrm{mg} \mathrm{Cd} \cdot \mathrm{kg}^{-1}$, de a városi terület $\mathrm{Pb}$ tartalma ennek nyolcszorosa, Cd-tartalma pedig a másfélszerese volt. Moszkvában és Washingtonban a 60 év feletti és a 10 év körüli városi területek talajait hasonlították össze. Tapasztalataik alapján az idősebb, jobb minőségü, alacsonyabb térfogattömegü, szervesanyagban gazdag talajokban a zavarás hatása idővel redukálódott (SCHARENBROCH et al., 2005).

LEHMANN (2007) a városi talajok speciális tulajdonságait (pl. a térfogattömeget) figyelembe véve a természetes talajokhoz hasonlóan értékelte az általa vizsgált technosolokat és anthrosolokat, megkönnyítve ezzel a talajosztályozási rendszerbe sorolásukat. Az évek előrehaladtával a fejlett országok már kiterjedt ismeretekkel rendelkeznek saját országaik városi talajairól, de 2010-ben már felmerült a fejlődő országok, pl. Kína és India eddig kevésbé szennyezett, de a rohamosan iparosodó területein elhelyezkedő talajok szennyeződése és pusztulása. A növekvő agglomerációval együtt tehát növekszik a talajszennyezettség és a városi talajokat érő hatások felerősödnek. A nehézfémek koncentrációja általában csökken az utaktól való távolsággal, valamint a talajmélységgel. A becslések szerint a kibocsátott ólom körülbelül 10\%-a 100 méteren belül lerakódik (MEUSER, 2010).

Az előbbi néhány példa is jól mutatja, hogy a városi talajok kutatásával foglalkozó szakemberek egyik legfontosabb feladata a szennyezett talajok toxikus elemeinek meghatározása és a szennyezés okainak felkutatása volt. Több kutató is foglalkozott ezzel, például Skóciában (ENTwiSTLE et al., 1998), Stockholmban 
(BERGBÄCK et al., 2001), Karlsruheban (NoRRA \& StÜBEN, 2003) vagy Hong Kongban (Li et al., 2004).

Magyarországon - mezőgazdasági jelentőségük miatt - számos kutatás és publikáció foglalkozik agrártudományi vonalon a talajban zajló mikro- és makro-tápelem körforgalommal. A föbb kutatási irányokat a $\mathrm{Zn}-, \mathrm{Cu}-, \mathrm{Pb}-, \mathrm{Cd}-$ és $\mathrm{Cr}-$ felhalmozódásának mértéke, a növényi részekben történő kimutatásuk és a szennyvíziszap szántó területekre való kijutattásának hatásai jelentik (pl.: GYŐRI, 1958; KÁDÁR, 1995; SiMON et al., 1999; SIMON et al., 2000).

Hazánkban, a városi területek feltárását a toxikus vagy eszenciális nehézfémek együttes vizsgálatával végezték; pl. a főváros közterületeinek vizsgálati eredményei szerint Budapesten az utak melletti átlagos nehézfémtartalom 2-5-szöröse is lehet a zöldterülteken mért átlagértékeknek (KOVÁCS \& NYÁRI, 1984). 1991-ben átfogó vizsgálat (talaj, növény/levélminta) is zajlott a Talajtani és Agrokémiai Kutatóintézetben, ahol mintánként 20-25 elem mérési eredményeit hasonlították össze az intézet kísérleti telepei szennyezetlen talaj- és növényelemzési adataival (KÁDÁR, 1995). Debrecenben jelenleg SÁNDOR és SZABÓ (2014) folytat szelvényvizsgálatokat a villamospálya felújítási munkálatok kapcsán. Korábban pedig SzEGEDI (1999) vizsgálta a város talajainak $\mathrm{Pb}$-, $\mathrm{Cd}$-, $\mathrm{Co}$-, $\mathrm{Ni}$ - és $\mathrm{Cu}$-tartalmát. A kerti talajok nehézfém vizsgálatai mellett (SzOLNOKI et al., 2013) pedig az új Magyar Talajosztályozási Rendszer kidolgozását segíti a szegedi technosol talajok széleskörü vizsgálata is (PUSKÁS \& FARSANG, 2007; PUSKÁS et al., 2008).

$\mathrm{A}$ városi területek talajainak legtoxikusabb eleme az $\mathrm{Pb} \mathrm{Az}$ Pb-terhelés annak ellenére jelentős, hogy Magyarországon a 1990-es évek elején betiltották az ólmozott benzin használatát. Lúgos közegben a kevéssé gyengén mozgékony ólom még a viszonylag sok és nagy intenzitású csapadék hatására sem mozdul el, vagyis a feltalajban tárolódik. Erre vonatkozóan több kutató talált összefüggést az Pb-tartalom és úttól való távolság között. SzEGEDI (1999) az utak melletti 2-20 m-en belül megemelkedett $\mathrm{Pb}$-szintet állapított meg, míg a többi elemnél nem tapasztalt összefüggést a távolsággal. A szegedi Bakó városnegyed kerti talajainak növekvő $\mathrm{Pb}$ szennyezettsége azonban az úttól való távolság függvényében változott (SzOLNOKI et al., 2013). Kisebb városokban, mint pl. Sopron, VARGA és munkatársai (1999) vizsgálták különböző forgalomintenzitású utcák városi fáinak környezetében a legfelső talajrétegeket $(0-5 \mathrm{~cm})$. A legforgalmasabb utca összes Pb-tartalma meghaladta a $100 \mathrm{mg} \cdot \mathrm{kg}^{-1}$ szennyezettségi határértéket. A szerzők a város talajainak állapotáról átfogó ismereteket is közöltek (HORVÁTH et al., 2014).

A cink a magasabb rendü növények számára nélkülözhetetlen mikrotápelem, mely állandóan jelen van használati eszközeinkben, háztartási termékeinkben (CSATHÓ, 1994). FÜGEDI és munkatársai (2007) felszínközeli üledékeket vizsgáltak az egész ország területén és rámutattak a szikesek és a meszes talajok cinkhiányára. Talajtípustól függően 14-600 $\mathrm{mg} \mathrm{Zn} \cdot \mathrm{kg}^{-1}$ értékeket mértek.

A réz megjelenését városi területeken a mélyben elhelyezett rézvezetékek korróziója okozhatja, mivel a felszínre kerülö $\mathrm{Cu}$ nagyobb része a bolygatatlan talaj felső néhány cm-ben kötődik meg (SzEGEDI, 1997b). Emellett a Cu-tartalmú növényvédőszerek jellemzően a szölö-területek feltalajában halmozódnak fel (HORVÁTH et al., 2014; NÉMETH et al., 2014). 
A kadmiumot inkább a mezőgazdasági területeken vizsgálnak, mivel a növények sok esetben látható tünetek nélkül juttatják a táplálékkörforgásba az akkumulálódott Cd-ot (SimON et al., 1999).

A kobalt természetes előfordulása $18 \mathrm{mg} \mathrm{Co} \cdot \mathrm{kg}^{-1}$, kis mennyiségben eszenciális, míg a nikkel estében ez az érték $25 \mathrm{mg} \mathrm{Ni} \cdot \mathrm{kg}^{-1}$ (CSATHÓ, 1994). E két mobilisabb elem könnyen a talaj mélyebb rétegeibe mosódhat, hisz az ólomhoz hasonlóan nem kötődnek a humuszhoz (SzEGEDI, 1997b). Döntően természetes forrásból (pl. az alapkőzetből) származnak, de az antropogén tevékenységből (pl. égetésből) eredően mennyiségük a talajban megemlekedhet. A Co kémiai tulajdonságai hasonlóak a mangánéhoz, így sokszor azzal együtt fordul elö. A pH növekedésével oldhatóságuk csökken (UREN, 2010), tehát a lúgos városi talajokban kevésbé felvehetöek.

A szakirodalomban irányadó határértéket találunk a talajszennyezettség kimutatására. Ezek a források tartalmazzák a talajban és a növényekben lévő nehézfémek normál illetve veszélyes koncentrációját (BLUME, 1992), vagy az erdei ökoszisztéma Pb- és Cd-bevételét (ZÖTTL, 1987).

A városi közlekedés során a nagyszámú forgalom miatt nagy mennyiségben kerülhetnek különböző fémek először a levegőbe, majd a talajba, valamint az út menti növényzetbe (FIEDLER, 1990). Az innen származó toxikus fémek legnagyobb hányada az üzemanyag elégetésekor (pl. az Pb), míg a további szennyezők a gépkocsik korroziójával (pl. Zn, Cu), illetve a gumiköpenyek kopásakor (pl. Cd) szabadulnak fel. Egyes fémeknek nincs érdemi káros hatása; $\mathrm{Az}$ általunk vizsgált $\mathrm{Cu}, \mathrm{Co}$, $\mathrm{Zn}$ és Ni kis mennyiségben eszenciális és csak nagy mennyiségben toxikus, de a Cd és az Pb akkumulálódva igen gyakran erősen mérgező lehet (BLUME, 1992; SzABÓ, 1996).

A fémek mobilitása a talajban pH-függő. A leggyakrabban a talaj felső, szervesanyag komplexeiben dúsulnak fel (ZÖTTL, 1987), de a hidrogénionok kiszoríthatják a fémionokat a humuszmolekulák és az agyagásványok felületéről (MCELDOwNEY et al., 1993, SzEGEDI, 1999b). Stabilitásuk a talaj savanyúságával csökken, amely nagymértékben lassítja, csökkenti a mélyebb rétegekbe jutásukat és így felvehetővé válhatnak a városi növények számára. A városi talajok kémhatása általában a lúgos tartományú (LEHMANN, 2007). A Cd és a Co mérsékelten mobilis, míg az ólom, a cink, a nikkel és a réz csak gyengén mobilis (MCELDOWNEY et al., 1993). A talajok fémtartalmának növekedésével csökken a növényi fajdiverzitás (fémtürők megjelenése), a talajbiológiai aktivitás.

Kutatásunk keretében arra kerestük a választ, hogy az antropogén tevékenység milyen hatást gyakorol a városi talajokra, illetve milyen összefüggés van a terület használat és a szennyezések között. További célunk volt annak megállapítása, hogy melyek a lokális szennyezettségi pontok, illetve ezek megjelenésének mi az oka.

\section{Anyag és módszer}

Kutatásainkat Sopron és Szombathely város közigazgatási területén végeztük. 
Sopron város területe már az öskor óta lakott, a statisztikai adatok szerint 61390 lakosa van, kiterjedése 16901 ha (KSH, 2012). Az ókorban és a középkorban virágzó kereskedelmi és kulturális csomópont volt, 1277-ben szabad király város rangot is kapott és vele a Suprun nevet. A török hódoltság ideje alatt Sopron volt a központja a töröktől független területeknek. 1676-ban tüzvész pusztította el a település nagyobb részét, a második világhaború alatt pedig több légi csapást is elszenvedett (ТóTH, 2011).

A város jelentősebb hányada a Soproni-medencében helyezkedik el, ami neogén üledékkel fedett (ÁDÁM et al., 2010). ÉK-röl a Fertö-melléki dombság és DNy-Nyról a Soproni-hegység határolja. A város mérsékelten hüvös éghajlatú, évente 500 $600 \mathrm{~mm}$ - a Soproni-hegységben $750 \mathrm{~mm}$ feletti - csapadék esik.

A Soproni-hegység 580-520 millió évvel ezelötti kambriumban keletkezett, így az ország talán legidősebb kőzetekből - gneisz, csillámpala - álló hegysége (FÜLÖP, 1990; BUDAI \& KONRÁD, 2011). Vízrajzi szempontból a legjelentősebb vízfolyása az Ikva-patak.

A Soproni-hegyvidék savanyú alapkőzetein elsősorban erősen savanyú nem podzolos, illetve podzolos barna erdőtalajok fejlödtek. A Soproni-hegyvidéken és a Fertő-melléki dombsoron lerakódott löszön agyagbemosódásos barna erdőtalajokat (haplic Luvisols, haplic Umbrisols) és barna földeket találunk. Az utóbbiak megtalálhatók a lajta mészkövön fejlődött rendzina talajok mellett is. A Sopronimedencében a barna erdőtalajok mellett, nagy kiterjedésben találhatók öntés és réti talajok (Fluvisols) is (RAJKAI \& TóTH, 2010), melyek a belvárosi területeken városi talajokká alakultak (NOVÁK, 2013; IUSS WORKING GROUP WRB, 2007).

Szombathelyen, az aktuális statisztikai adatok alapján, 79348 lakos él 9750 haon (KSH, 2012). Történeti érdekessége, hogy a legrégebben alapított város Magyarországon, amit egy földrengés elpusztított Kr. u. 456-ban. A város a DK-i lejtésủ Gyöngyös síkon terül el, melynek felszínét jégkorszaki vályog, agyagos vályogos löszös üledék és lösz borítja. A legfontosabb vízfolyások a Perint és a Gyöngyös, amelyek átszelik a várost.

A Gyöngyös és a Perint völgyében kis szervesanyag-tartalmú, karbonátmentes, nyers öntéstalajok (dystric Fluvisols) találhatók. A peremterületeken lévő barna erdőtalajok (haplic Umbrisols) pedig itt is városi kevert talajokká alakult a belvárosi részeken (NOVÁK, 2013). Megjegyzendő, hogy mivel kutatásunk során csak pontmintavételekre volt lehetőség a talaj felső $20 \mathrm{~cm}$-éből, ezért a továbbiakban a talajosztályozással nem foglalkozunk.

A város éghajlata mérsékelten hüvös-mérsékelten száraz, az évi középhőmérséklet $9,0-9,5^{\circ} \mathrm{C}$. Az évi csapadék sokéves átlaga $630-650 \mathrm{~mm}$. A talajvíz mélysége a Sorok-Perint völgyében 2-4 m közötti, máshol négy méter alatt van. Szombathely térsége a mezőgazdálkodás számára alkalmas talajok miatt csaknem erdőtlenné vált (RAJKAI \& TÓTH, 2010). A természeti adottságok és a jellemző tájhasználat hatást gyakorol a talajtulajdonságokra.

A mintavételek időpontja a 2011 tavaszán volt a talajmenti fagyok megszünése után, a rügyfakadás kezdetén. A kutatási területeken, folytonos alapsokaságon értelmezett random bolyongásos módszerrel felvett rácspontokban vizsgáltuk a talajok állapotát. A városok közigazgatási területeire egy rácshálót illesztettük. 
A véletlen ("random") mintavétel során az alapsokaság minden egyede és a lefedett terület bármely pontja egyforma eséllyel került a mintába. A minta elemeit pedig egymástól függetlenül választottuk ki. Tehát nem a potenciális szennyezések feltárása, hanem a város állapotának feltérképezése volt a cél. A mintavételi pontok egymástól való távolsága belterületen $0,5 \mathrm{~km}$, külterületen pedig $1 \mathrm{~km}$ volt.

Sopronban 104, Szombathelyen pedig 88 pontban gyüjtöttünk mintákat a $0-10$ és a 10-20 cm-es talajrétegből, tehát összesen 384 minta vizsgálatát végeztük el (1. ábra).
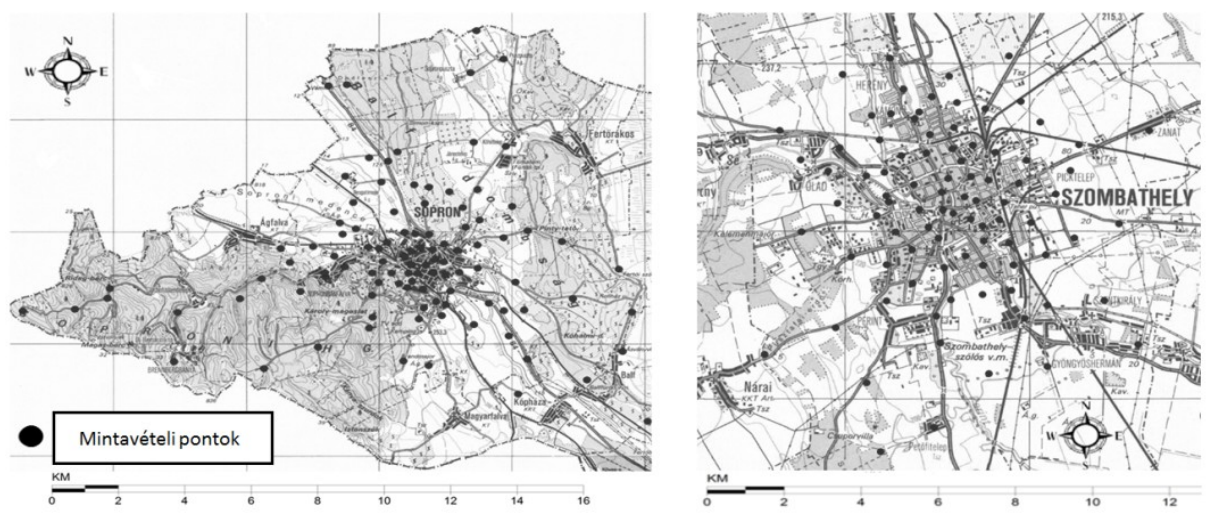

1. ábra

Mintavételi pontok elhelyezkedése a mintaterülteken

A minták begyüjtése az általunk kiválasztott pontokon a felület letisztítását követően egy 30x30 cm-es négyzet kijelölése után ásóval történt. A minták kiemelése után mérőszalaggal ellenőriztük a mintavételi mélységeket. Szakmai szempontból azért választottuk a talaj felső $20 \mathrm{~cm}$-ének elemzését, mert véleményünk szerint ez a réteg a legalkalmasabb az esetleges szennyezések kimutatására, hisz a felső $40 \mathrm{~cm}$ ben a legnagyobb a talajaktivitás. Ezen kívül a régebbi és a jelenleg is zajló kutatások eredményei szerint a talajba került nehézfémek nem mosódnak a 20 cmnél mélyebbre (SIMON et al., 2000; CARRE et al., 2013). Mivel nem természetes, hanem városi környezetben történtek a mintavételek, csak kevés esetben tudtunk eredeti talajmintát venni még a külvárosban is. A minták túlnyomó része kevert, illetve zavart talajkörnyezetből származik, így a genetikai talajrétegek elkülönítésére nem volt mód.

A mintavétel során jegyzőkönyvben rögzítettük a pont helyzetét (GPS koordináta) és környezetének föbb tulajdonságait - a jellemzö területhasználatot, a növényzetet, a talaj eredetét, a tengerszint feletti magasságot, a gyüijtés idejét, a lakókörzet típusát. A talajminták esetén a következő paramétereket írtuk le: átmenet, humuszmennyiség, szerkezet, tömődöttség, gyökérzet, szín, fizikai féleség, kiválás, talajhiba, müterméktartalom, Munsell-szín.

A laboratóriumi mérések során elsőként a talajok kémhatását (potenciometriás mérés; desztillált vizes és KCl-os kivonattal - MSz 08-0206-2:1978), kalcium- 
karbonát- (Scheibler-féle kalciméter; MSz 08-0205:1978) és szervesanyag-tartalmát (FAO, 1990), illetve - a szemcseeloszlás és az Arany-féle kötöttségi szám alapján fizikai féleségüket határoztuk meg - (MSz 08-0205:1978). Ezeken kívül végeztünk összes nitrogén, ammónium-laktát-oldható $\mathrm{K}$ - és P-tartalom, $\mathrm{KCl}$-oldható Ca- és Mg-tartalom, valamint az EDTA/DTPA-oldható Fe-, $\mathrm{Mn}$-, $\mathrm{Cu}$ - és $\mathrm{Zn}$-tartalom vizsgálatokat. Utóbbiak ereményeit már korábban bemutattuk (HORVÁTH et al., 2013a). A laboratóriumi vizsgálatokat a Nyugat-magyarországi Egyetem Termőhelyismerettani Intézeti Tanszékének laboratóriumában végeztük.

A mérési eredményeket digitálisan rögzítettük, majd térinformatikai módszerekkel dolgoztuk fel (DigiTerra Map), továbbá következtetéseket vontunk le a helyszíni adatok, a laboratóriumi értékek és az elkészített tematikus térképek alapján. Eredményeink kiértékeléséhez több szakirodalmi értékelést és összehasonlítást végeztünk BELlÉR (1997), SzABOLCS (1966), FILEP (1999) és FÜLEKY (1999) munkái alapján. A minták nehézfémtartalmát, a Lakanen-Erviö módszer szerinti előkészítést követően (MSz 21470-50:2006) ICP-OES (ICAP 6000 Series) készülékkel mértük meg. A mérés során 24 elem koncentrációját határoztuk meg, melyek közül az általunk legmeghatározóbbnak ítélt hat elem $(\mathrm{Cd}, \mathrm{Co}, \mathrm{Cu}, \mathrm{Ni}, \mathrm{Pb}, \mathrm{Zn})$ mennyiségét emeltük ki.

A vizsgálatokat a Termőhelyismerettani Intézeti Tanszék talajtani laboratóriumában végeztük, amely akkreditálva van talajtani alapvizsgálatokra. Az elemtartalmi vizsgálatok megfelelősége érdekében, rendszeresen részt veszünk a FOREST SOIL CO-ORDINATING CENTRE (FSCC)-INBO által szervezett nemzetközi körmérésben.

A statisztikai adatok kiértékelését STATISTICA 11 (ANOVA, Basic Statistic) program segítségével készítettük el.

\section{Eredmények és értékelésük}

A mintákat először a városi környezetre jellemző területhasználati kategóriákba soroltuk. A 2. ábrán látható, hogy Sopronban az erdőterületekről származó mintákból van a legtöbb (28 db), míg Szombathelyen a patak- és vízpartról származó mintákból $(22 \mathrm{db})$. Szombathelyen a két patak teljes hosszában áthalad a városon, észak-déli irányban, a soproni erdős területek pedig hozzátartoznak a város jellegéhez. Korábban jellemző volt a várost körülvevő hegyvidéken létesített erdei kertek üdülési célú kialakítása is, de ez az egyedi táj- és építészeti jelleg mára eltűnőben van. A minták 42\%-át lakóövezetből, közlekedési zónából és ipari területről gyüjtöttük, melyek aránya is jól mutatja, hogy a természetközeli területek aránya még bizonyos mértékig egyensúlyban van az emberi jelenlét mértékével.

Szombathelyen a minták 25\%-a származott patak- és vízpartról, 23\%-a közlekedési zónából, illetve 19\%-uk lakóövezetből, így a minták 46\%-a származik folyamatos emberi akitivitásnak kitett területröl.

A Sopron várost övező Soproni-hegység erdőterületein a talajok kémhatása savanyú $\left(\mathrm{pH}\left(\mathrm{H}_{2} \mathrm{O}\right)\right.$ átlagosan 4,9$)$. Ennek oka a metamorf alapközet és az erőteljes kilúgzás. 


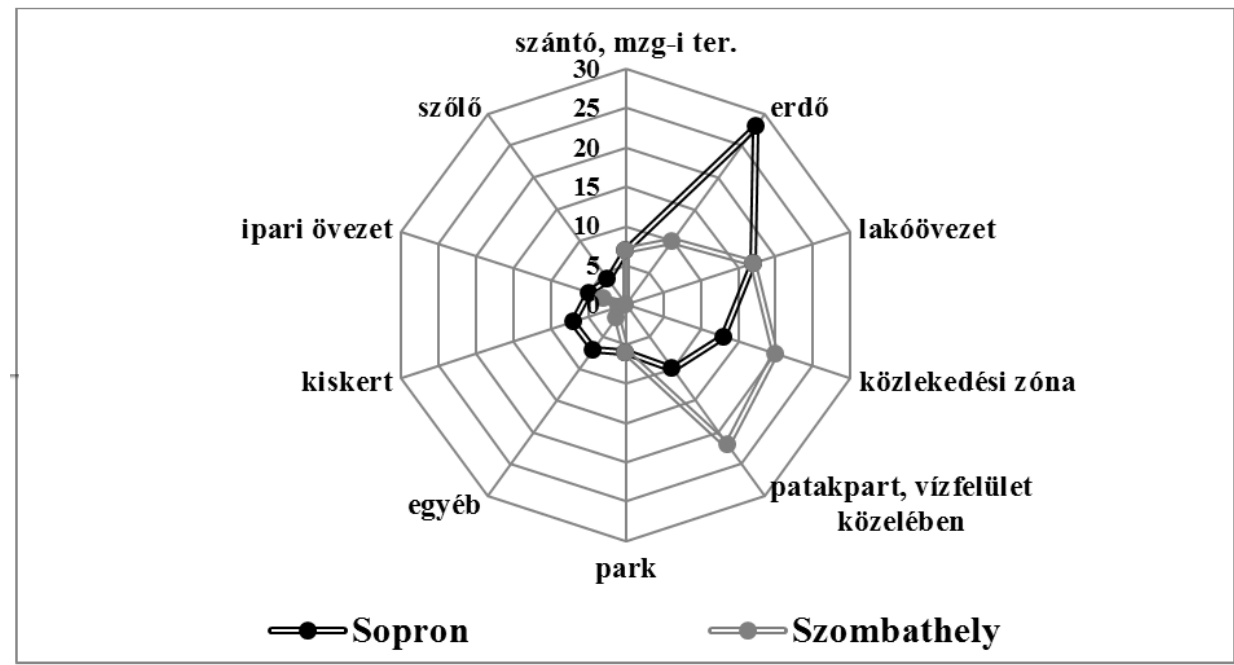

2. ábra

A mintavételi pontok megoszlása területhasználati kategóriák szerint

A város Soproni-medencében elterülő része a geológiai körülmények miatt és emberi hatásra lerakódott meszes üledékkel fedett, így az onnan származó minták gyengén lúgosak vagy lúgosak $(7,3-8,0)$ mindkét rétegben. A minták $78 \%$-ának vizes $\mathrm{pH}$-ja magasabbnak bizonyult az alsó vizsgált rétegben $(10-20 \mathrm{~cm})$. Tehát eredményeink New York talajainak kémhatásához hasonlóan 8,0 körüli értékek voltak (CRAUL, 1992).

Szombathely talajainak kémhatása 5,5 és 8,2 közé esett, átlagosan pedig semleges $(\mathrm{pH} \sim 6,9)$. A külvárosban és a peremterületen a Soproni-hegységhez képest kevésbé savanyú erdöterületek, a város körül inkább szántóföldek találhatók. Ez utóbbiakra jellemző a mütrágya használat. A belvárosban - az öntéstalajok miatt - a semleges és a gyengén lúgos kémhatás jellemző. A pH( $\mathrm{KCl})$ mérési eredmények követték a vizes $\mathrm{pH}$-értékek változását.

A két település talajainak lúgos kémhatása a növények által felvehető toxikus elemek megkötésének szempontjából kedvezö, mivel így nem válnak mozgékonnyá, illetve felvehetővé a talajoldatból. Ugyanakkor azonban kedvezőtlen is, mert ezen elemek a humuszanyagokhoz és az agyagásványokhoz kötődve akkumulálódhatnak. Ettől eltekintve véleményünk szerint a jövőben egyre nagyobb problémát jelenthet a növekvő talajszennyezettség a külvárosi és a peremterületek savanyú erdő területein, mivel egyre jelentőssé válik az áthaladó forgalom. A közlekedésből származó toxikus elemek mozgékonnyá válnak savas közegben és a mélyebb rétegekbe jutva a vízbázisokat is elszennyezhetik, a jövőben pedig akár kibocsátó forrásokká is válhatnak.

A soproni minták háromnegyede tartalmazott $\mathrm{CaCO}_{3}$-t átlagosan $11 \%$-ot mindkét vizsgált rétegben. A meszes üledékkel borított belvárosi részen magasabb érté- 
keket mértünk $\left(20 \% \mathrm{CaCO}_{3}\right)$. A minták harmada a külvárosból származott, mégis hasonlóan magas értékek voltak jellemzők, melynek oka a talajba került mütermékek, hulladékok és építési törmelékekböl eredhet. Mivel a terület az őskor óta lakott, ezért természetes eredetủ talajjal csak ritkán találkoztunk.

A szombathelyi minták fele nem tartalmazott $\mathrm{CaCO}_{3}$-ot. $\mathrm{A}$ városban a mésztartalom a belvárosból kiindulva a külváros felé csökken. $\mathrm{A} \mathrm{CaCO}_{3}$-tartalom átlagosan 5\%-os mindkét rétegben, ami éppen elég ahhoz, hogy a talaj pufferkapacitásának egyensúlyát fenntartsa az antropogén eredetű savanyító hatásokkal szemben.

A szénsavas mésztartalom és a talajok kémhatása közötti korrelációs kapcsolat mindkét városban szignifikáns $(\mathrm{p}<0,05)$. (Szombathelyen a $0-10 \mathrm{~cm}$-es rétegé: $\mathrm{R}^{2}=$ 0,75 ; a $10-20$ cm-es rétegé: $\left.\mathrm{R}^{2}=0,78\right)$.

A talajok fizikai féleségét mechanikai összetételük és Arany-féle kötöttségi számuk $\left(\mathrm{K}_{\mathrm{A}}\right)$ alapján határoztuk meg; A soproni minták 30\%-a agyagos vályog, 27\%-a agyag, 15\%-a nehéz agyag, 13\%-uk pedig vályog fizikai féleségü. A szombathelyi felső rétegből származó minták $41 \%$-a agyagos vályog és $41 \%$-a agyag kategóriába tartozik. A $10-20 \mathrm{~cm}$-es rétegben több minta tartozott a vályog kategórába (29\%), és $41 \%$ volt agyagos vályog fizikai féleségü.

Összességében tehát a mintákban dominált az agyag fizikai féleség. Az ilyen talajoknak jellemzően jó a víztartóképessége. Jól tárolják a vizet, de a tárolt víz nehezen elérhető a növények számára (STEFANOVITS, 1992). Ezekben a talajokban felhalmozódhatnak továbbá az agyagásványokhoz kötődő toxikus elemek pl: az $\mathrm{Pb}, \mathrm{a}$ $\mathrm{Zn}$ és a $\mathrm{Cu}$, amelyek azonban a savanyodás hatására mobilizálódhatnak.

Mgjegyezzük továbbá, hogy Sopron DNy-i részén a kötöttségi értékek gyakran kiemelkedően magasak voltak mindkét vizsgált rétegben. Több talajminta elemzése során a magas kötöttséghez nagy humusz- és nitrogén N-tartalom értékek tartoztak a külvárosi területeken. Ennek valószínü oka, hogy a dúsabb növényzet lehullott, magas nedvességtartalmú és tápanyagban gazdag avarrétege kevésbé bolygatott, ezért a lebontó folyamatok is gyorsan végbe mennek. A másik magyarázat az lehet, hogy a humusztartalom növeli a víztároló kapacitást, ami viszont növeli a kötöttségi értéket - elsősorban a város fákkal borított területein (BIDLÓ et al., 2012).

A szervesanyag-tartalmat tekintve egy érdekességet figyeltünk meg. Habár a város talaja szeves anyagban gazdag, mégis igen alacsony értékeket találtunk a Perint partról, a 0-10 cm-es talajrétegböl származó mintákban. RAJKAI és TóTH (2010) említést tesznek a löszös üledéken képződött barnaföld termékenyégéröl, valamint a Perint völgyének alacsony szervesanyag-tartalmú öntéseiről. Utóbbit méréseink igazolták.

A nehézfémtartalmi eredmények kiértékelésében irányadónak a Magyarországon hatályos 6/2009. (IV. 14.) KvVM-EüM-FVM és a 10/2000. (VI. 2.) KöMEüM-FVM-KHVM együttes rendeletet vettük figyelembe. A rendeletekben kijelölt és a KÁDÁR (1998) által javasolt határértékeket illetve a mért ereményeket - az általunk kiemelten vizsgált hat toxikus elemre - az 1. táblázatban foglaltuk össze.

A 1. táblázatban mind a Soproban és mind a Szombathelyen mért nehézfémtartalmakat egyaránt közöltük, de a későbbiekben csak a szombathelyi minták nehézfémértékeit tárgyaljuk, mivel a soproni eredményeket már korábbi munkáinkban összefoglaltuk (HORVÁTH et al., 2013a; HORVÁTH et al., 2014). 
1. táblázat

A javasolt határértékek és az egyes elemek általunk mért értékeinek összehasonlítása

\begin{tabular}{|c|c|c|c|c|c|c|c|}
\hline $\begin{array}{c}\text { (1) } \\
\text { Mélység }\end{array}$ & \multirow{2}{*}{$\begin{array}{c}\text { (2) } \\
\text { Staisztikai } \\
\text { mutató }\end{array}$} & $\mathrm{Cd}$ & Co & $\mathrm{Cu}$ & $\mathrm{Ni}$ & $\mathrm{Pb}$ & $\mathrm{Zn}$ \\
\hline $\mathrm{cm}$ & & \multicolumn{6}{|c|}{$\mathrm{m} \cdot \mathrm{kg}^{-1}$} \\
\hline \multicolumn{8}{|c|}{ Sopron $(n=104)$} \\
\hline \multirow{3}{*}{$0-10$} & a) Átlag & 0,16 & 2,06 & 11,84 & 2,57 & 12,45 & 13,30 \\
\hline & Min. & 0,04 & 0,36 & 1,15 & 0,55 & 2,76 & 2,68 \\
\hline & Max. & 0,67 & 6,42 & 122,1 & 9,87 & 55,87 & 60,65 \\
\hline \multirow{5}{*}{$10-20$} & b) Szórás & 0,08 & 1,12 & 20,37 & 1,41 & 8,44 & 11,11 \\
\hline & a) Átlag & 0,15 & 2,11 & 12,14 & 2,53 & 12,05 & 10,16 \\
\hline & Min. & 0,02 & 0,54 & 1,09 & 0,41 & 2,54 & 1,64 \\
\hline & Max. & 0,61 & 5,59 & 144,90 & 7,10 & 58,67 & 57,86 \\
\hline & b) Szórás & 0,09 & 1,13 & 23,35 & 1,43 & 9,88 & 9,81 \\
\hline \multicolumn{8}{|c|}{ Szombathely $(n=88)$} \\
\hline \multirow{3}{*}{$0-10$} & a) Átlag & 0,14 & 2,11 & 7,74 & 3,84 & 11,19 & 16,41 \\
\hline & Min. & 0,02 & 0,71 & 2,08 & 1,05 & 1,60 & 2,45 \\
\hline & Max. & 0,62 & 6,05 & 35,87 & 14,20 & 144,00 & 100,70 \\
\hline \multirow{5}{*}{ 10-20 } & b) Szórás & 0,10 & 0,82 & 5,98 & 2,32 & 16,86 & 16,58 \\
\hline & a) Átlag & 0,12 & 2,16 & 7,43 & 3,87 & 12,20 & 13,20 \\
\hline & Min. & 0,02 & 0,56 & 1,71 & 0,96 & 1,67 & 1,20 \\
\hline & Max. & 0,60 & 7,10 & 30,38 & 14,71 & 264,90 & 101,80 \\
\hline & b) Szórás & 0,09 & 1,01 & 4,90 & 2,32 & 28,87 & 14,80 \\
\hline \multicolumn{8}{|c|}{ A. Határértékek } \\
\hline \multicolumn{2}{|c|}{, $\mathrm{A}^{\prime \prime} \mathrm{m} \cdot \mathrm{kg}^{-1}$} & $0,5^{*}$ & 5 & 10 & 10 & 10 & 5 \\
\hline \multicolumn{2}{|c|}{ „B” m·kg-1 } & $1^{*}$ & 10 & 40 & 20 & 25 & 20 \\
\hline \multicolumn{2}{|c|}{, $\mathrm{C}^{\prime \prime} \mathrm{m} \cdot \mathrm{kg}^{-1}$} & - & 20 & 90 & 60 & 70 & 40 \\
\hline
\end{tabular}

Megjegyzés:* a Cd esetében a Kármentesítási kéziköny 2. (Kádár, 1998) nem határozott meg határértéket, ezért a kiértékelésnél a 6/2009. (IV. 14.) KvVM-EüM-FVM és a 10/2000. (VI. 2.) KöM-EüM-FVM-KHVM együttes rendeletet vettük figyelembe. „A” a természetes határkocentráció; „B” a szennyezettségi határérték és „C” az első intézkedési határérték.

A szombathelyi városi talajok rétegeinek nehézfémtartalom összefüggéseit vizsgáltuk meg. Megállapítottuk, hogy egy ponton egy-egy elemre nézve a rétegek között szoros a kapcsolat. A kiemeleten vizsgált hat elem közül a legszorosabb kapcsolatot az $\mathrm{Pb}$-tartalom $\left(\mathrm{R}^{2}=0,94\right)$ esetében találtuk (3. ábra).

A leggyengébb korreláció a két vizsgált réteg $\mathrm{Zn-értékei}\left(\mathrm{R}^{2}=0,77\right)$ között mutatkozott $\mathrm{p}<0,05$ szignifikancia szinten. Megállapítható, hogy jelentős éltérés nincs az egy ponton egymás fölött elhelyezkedő rétegek között a $\mathrm{Cd}, \mathrm{Co}, \mathrm{Cu}, \mathrm{Ni}, \mathrm{Pb}$ és $\mathrm{Zn}$ koncentrációjában. 
$\mathrm{Pb} 0-10 \mathrm{~cm}$ vs. $\mathrm{Pb} 10-20 \mathrm{~cm}$

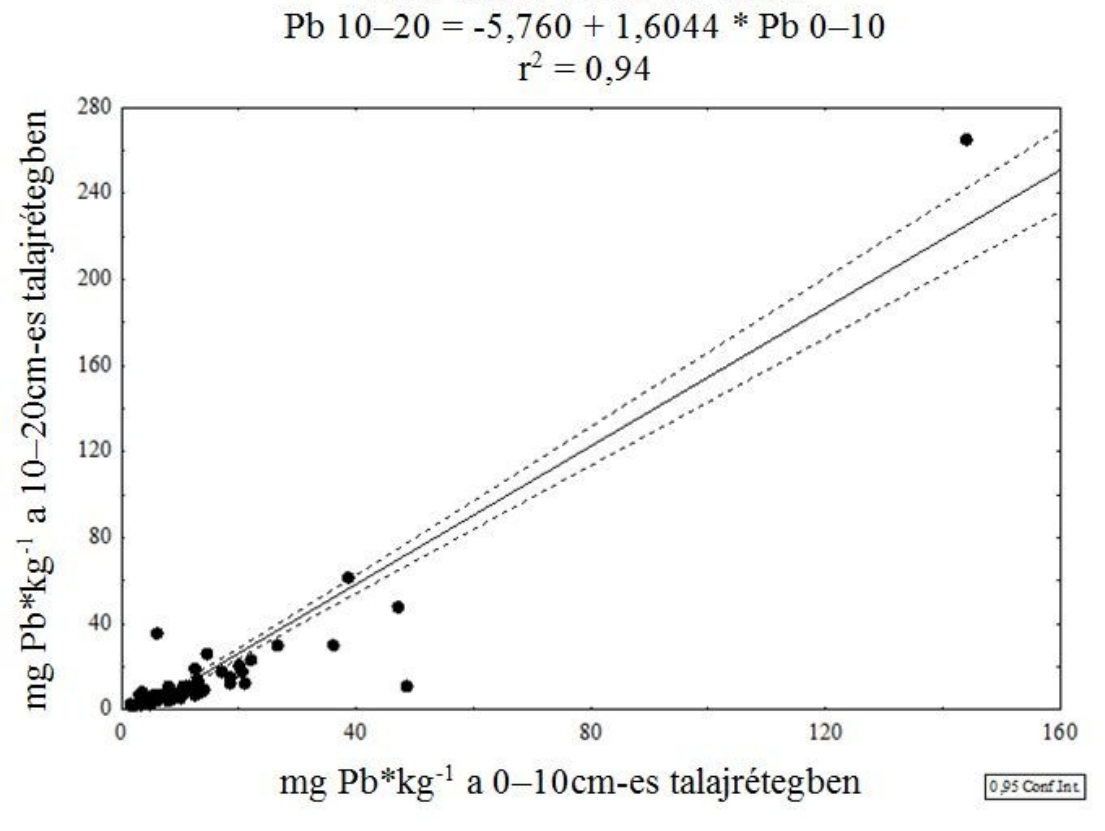

3. ábra

A szombathelyi talajok alsó talajrétegének $\mathrm{Pb}$-tartalma a felső réteg Pb-tartalmának függvényében

Megjegyezzük, hogy egyértelműen nem jelenthető ki minden elem esetében, hogy a 0-10 cm-es réteg a nehézfém terheltebb. A felső rétegben több pont van a szennyezettségi határérték felett, az alsó rétegben mértnél. Megjegyzendő továbbá, hogy bár az alsó rétegben kevesebb esetben volt határérték túllépés, de ha volt, akkor az jelentős volt. Ennek legfőbb oka az elemek adott ponton mért kémhatástól függő mobilitása, amelyet befolyásol még a mintavételi pont helye és a pontot érő terhelés mértéke.

A mintáknak csak alig 1/5-e haladta meg Cu-értékekre KÁDÁR (1998) által javasolt természetes háttérkoncentráció szintjét $\left(10 \mathrm{mg} \mathrm{Cu} \cdot \mathrm{kg}^{-1}\right)$. Az idevonatkozó szennyezettségi $\left(40 \mathrm{mg} \mathrm{Cu} \cdot \mathrm{kg}^{-1}\right)$, illetve az intézkedési határértékek $\left(\mathrm{C}_{1}: 90-140\right.$; $\mathrm{C}_{2}$ : 140-190; $\mathrm{C}_{3}:>190 \mathrm{mg} \mathrm{Cu} \cdot \mathrm{kg}^{-1}$ - terület érzékenységétől függően) alapján pedig nem volt túllépés. A parkokban (max. $\mathrm{Cu}=35,87 \mathrm{mg} \cdot \mathrm{kg}^{-1}$ ) és a közlekedési zónákban gyüjtött pontmintákban (max. $\left.\mathrm{Cu}=28,96 \mathrm{mg} \cdot \mathrm{kg}^{-1}\right)$ a „B” határértéket közelítő értékeket mértünk.

A Gyöngyös partján három egymáshoz közeli talajmintában is a természetes háttérkoncentrációt meghaladó $\mathrm{Cu}$-tartalmat mértünk $\left(\max . \mathrm{Cu}=15,56 \mathrm{mg} \cdot \mathrm{kg}^{-1}\right) . \mathrm{A}$ belvárosban mért magasabb értékeket véleményünk szerint a talajban elhelyezett rézvezetékek korróziója okozhatja. A korábbi kutatások szerint, ha a talajt nem bolygatják, a felszínre kerülő réz nagyobb része a felső néhány cm-en kötődik meg (SZEGEDI, 1999b). 
Lineáris az összefüggés a $\mathrm{Cu}$-, $\mathrm{Pb}$ - és $\mathrm{Zn}$-tartalmak között a különböző talajrétegekben. A legszorosabb korreláció a Cu és $\mathrm{Zn}\left(\mathrm{R}^{2}=0,65\right)$ között a $10-20 \mathrm{~cm}$-es mélységben mutatkozott, mely a felsőbb rétegben gyengébbnek bizonyult $\left(\mathrm{R}^{2}=\right.$ 0,58), de kimutatható kapcsolat volt a 10-20 cm-es Cu-értékek és felső réteg $\mathrm{Zn}$ értékei között is $\left(\mathrm{R}^{2}=0,60\right)$. Az Pb-tartalom szintén mindkét mélységben korrelált az alsó réteg Cu-tartalmával $\left(0-10 \mathrm{~cm}: \mathrm{R}^{2}=0,61\right.$ és $\left.10-20 \mathrm{~cm}: \mathrm{R}^{2}=0,55\right)$. Ezek megerösítik a korábban atomabszorpciós spektrofotométerrel mért EDTA/DTPAolható tápelem vizsgálatok eredményeit (HORVÁTH et al., 2013b).

Gyenge lineáris kapcsolat állapítható meg a Ni- és a Co-tartalom között $\left(\mathrm{R}^{2}=\right.$ $0,51)$ a felső talajrétegben. Alacsony koncentrációban mind a Co, mind a Ni alapvető fontosságúak az élő szervezetek számára. Ezeknek a nehézfémeknek néhány vegyülete az alapkőzet alkotója, ugyanakkor technogén tényezők, pl.: égetés következtében felhalmozódhatnak a felső talajrétegekben is. A kobalt és a nikkel a talaj 0-10 cm-es rétegjében nem akkumulálódott, hanem koncentrációjuk a mélységgel növekedett. Az általunk készített térképek alapján megállapítható, hogy míg a felső rétegben kevesebb a mennyiségük az alsó rétegben már a természetes háttérkoncentrációhoz közeli értékekkel fordulnak elő. Ez azt jelenti, hogy e két mobilisabb elem a mélyebb rétegekbe mosódott. Ez valószínüleg azzal magyarázható, hogy az ólomhoz hasonlóan ezek a fémek nem kötődnek a humuszhoz (SzEGEDI, 1999a). Nyolc minta esetében haladta meg a Ni- és a Co-tartalom a természetes háttérkoncentrációt $\left(5 \mathrm{mg} \mathrm{Co} \cdot \mathrm{kg}^{-1} ; 10 \mathrm{mg} \mathrm{Ni} \cdot \mathrm{kg}^{-1}\right)$.

A begyüjtött talajminták $28 \%$-a, azaz 50 ta a 176-ból, haladta meg a KÁDÁR (1998) által javasolt ólomtartalom határértéket $\left(10 \mathrm{mg} \mathrm{Pb} \cdot \mathrm{kg}^{-1}\right)$. Ebböl 13 ponton magasabb volt, mint a szennyezettségi küszöbérték $\left(25 \mathrm{mg} \mathrm{Pb} \cdot \mathrm{kg}^{-1}\right)$ és két pontban még az intézkedési határétéknél $\left(\mathrm{C}_{1}: 70-150 ; \mathrm{C}_{2}: 150-300 ; \mathrm{C}_{3}:>300 \mathrm{mg} \mathrm{Pb} \cdot \mathrm{kg}^{-1}-\right.$ területérzékenységétöl függően) is többnek bizonyult. A belvárosi közlekedési zónák, vagyis a forgalmas utak mellől gyüjtött talajok ólommal szennyezettek, mivel ezeken a helyeken folyamatos terhelésnek kitettek a jármüvek miatt. A városok talajainak ólomterhelése annak ellenére magas, hogy Magyarországon a 90-es évek elején betiltották az ólmozott benzin használatát. A lúgos közegben gyengén mozgékony ólom a viszonylag sok és erős intenzitású csapadék ellenére a feltalajban halmozódik fel. A mintákban talált Pb-tartalom több esetben is meghaladta a vonatkozó rendeletben megszabott intézkedési szennyezettségi határértéket $(25 \mathrm{mg}$ $\mathrm{Pb} \cdot \mathrm{kg}^{-1}$ ) még abban az esetben is, ha feltételezzük, hogy "kevésbé érzékeny" területről van szó. Az időszakos forgalom lehetővé teszi, hogy a kibocsátott szennyező anyag a felszínre ülepedve a humuszanyagokon megkötődjön és felhalmozódjon. Tehát a talaj felső rétegében, a nagy forgalmú belvárosból kifelé haladva, a forgalom csökkenésével az ólomtartalom kismértékben csökkenhet.

A külvárosi savanyú kémhatású területek felé haladva a kisebb forgalom is veszélyes lehet az ólom mozgékonyságának növekedése miatt. Szombathely ipari körzeteiben a közlekedési zónák mellett kiugró értékek fordultak elő a felső talajrétegben is, melynek oka a rendszeres tehergépjármü forgalom lehet.

KÁDÁR (1993) ólomfelhalmozódást mutatott ki a forgalmas útszakaszok közelében és az ipari zónákban a Lakanen-Erviö módszerrel (CSATHÓ, 1994) (4. ábra). 


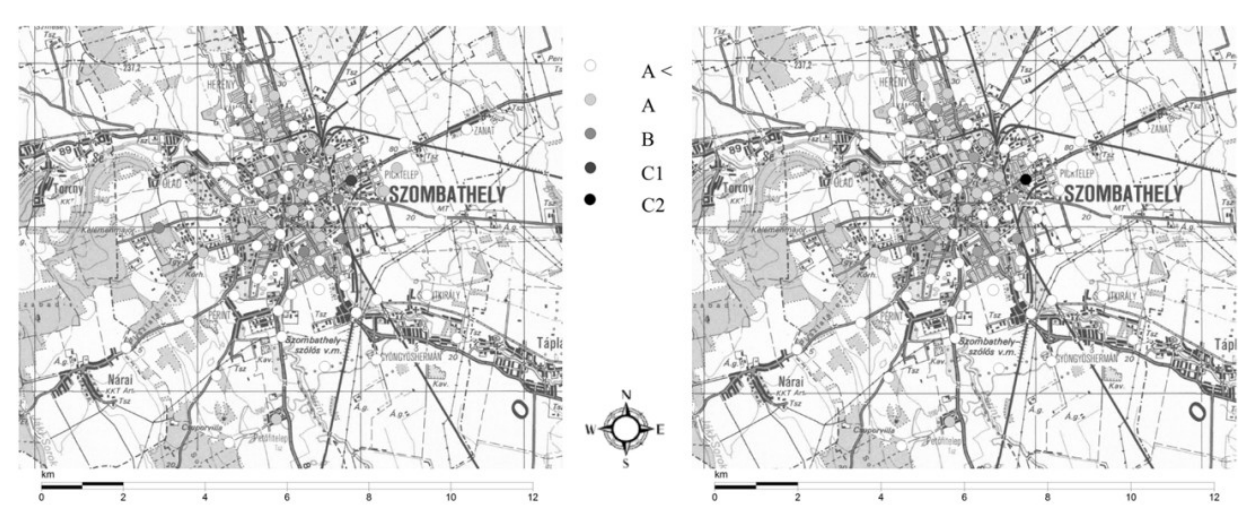

4. ábra

Ólomtartalom a 0-10 cm-es és a 10-20 cm-es talajmélységben (KÁDÁR 1998 alapján)

Az általunk készített szennyezettségi térképeken jól látható, hogy a folyamatos terhelésnek kitett belvárosi pontokon mindkét vizsgált rétegben vannak ólommal szennyezett mintavételi helyek.

A kadmium por vagy füst formájában mérgező, oldott formában erősen mérgező. A Cd-értékek nagyon alacsonyak voltak a város egész területén mindkét vizsgált rétegben. A begyüjtött minták közül egy sem haladta meg az elöírt Cd-tartalom szennyezettségi határértéket $\left(1 \mathrm{mg} \mathrm{Cd} \cdot \mathrm{kg}^{-1}\right)$. A magas Cd-értékek a valószínűsíthetőbb esetekben hulladékégetésből, szennyvizekből és a közlekedésből - gépjármügumik kopásából - származnak, azonban erre utaló jeleket nem találtunk. A Cdtartalom nagy forgalmú utak mentén $3 \mathrm{mg} \cdot \mathrm{kg}^{-1}$ közeli értéket is elérhet (SIMON et al., 1999) . Veszélye abban rejlik, hogy míg a lúgos talajokban jelentős a specifikusan adszorbeált Cd aránya, a savanyú talajú erdő területeken a növények számára hozzáférhetö lehet.

A minták 78\%-a (138 db a 176 db-ból) meghaladta a javasolt természetes háttérkoncentrációt $\left(5 \mathrm{mg} \mathrm{Zn} \cdot \mathrm{kg}^{-1}\right) .41 \mathrm{db}$ minta túllépte a $20 \mathrm{mg} \mathrm{Zn} \cdot \mathrm{kg}^{-1}$ szennyezettségi határértéket, melyböl $14 \mathrm{db}$ Zn-koncentrációja meghaladta az első intézkedési küszöbértéket, kettő pedig a másodikat is $\left(\mathrm{C}_{1}: 40-80 ; \mathrm{C}_{2}: 80-160 ; \mathrm{C}_{3}\right.$ : > $160 \mathrm{mg} \mathrm{Zn} \cdot \mathrm{kg}^{-1}$ - területérzékenységétől függően). A szennyezett talajokat $0-10$ $\mathrm{cm}$-es mélységben detektáltunk. A jelenlévő cinknek csak egy része származik a közlekedésböl. A Zn és vegyületei az antropogén hatások állandó kíséröi, mert háztartási eszközökben, ipari és mezőgazdasági felhasználású anyagokban egyaránt jelen vannak.

Szombathely külvárosában aktív mezőgazdasági tevékenység folyik jelenleg is. A város területét tekintve a $\mathrm{Zn}$-tartalom jellemzően határérték alatti, ezért növekedése nem mutat egyértelmü összefüggést a forgalom nagyságával, mivel csak töredéke származtatható gépjármüvekből (SzOLNOKI et al., 2013). Magas Zn-tartalom volt jellemzö a Gyöngyös patak partjáról származó mintákban.

A területhasználati kategóriák terheltségéröl elmondhatjuk, hogy megoszlásuk átlagértékei és szórása alapján nem tudunk egyértelmű tendenciát megállapítani. 
Kiértékelésük során két nagyobb terhelést figyeltünk meg. A legnagyobb terhelést közlekedési zónákban mértük, mely a megnövekedett és folyamatos jármüforgalomra vezethető vissza. Az összes elemre nézve legmagasabb összterhelést a belés külvároson átfutó Gyöngyös patak partjának talajában találtuk/mutattuk ki mindkét rétegben. Összehasonlításul - más geológiai és talaképződési folyamatok között - a Sopronban mért terhelés emelkedett ki. A legnagyobb terhelést a kiskertekben és szőlökben mértük, melyet a külterületeken alkalmazott $\mathrm{Cu}$-tartalmú vegyszerek használata okozott. Az összes elemre nézve a legmagasabb összterhelést a belvárosi parkok talajában mértük mindkét talajszintben.

A más magyar városokban végzett kutatásokhoz hasonlóan Szombathelyen is találtunk szennyezettségi határétéket meghaladó értékeket a közlekedési zónákban (KOVÁCS \& NYÁRI, 1984), valamint a zöldterületeken (SzOLNOKI et al., 2013), de az általuk leírtnál kisebb mértékben. SÁNDOR és SZABÓ (2014) a 0-20 cm-ben átlagos 30-40 mg Pb $\mathrm{kg}^{-1}$ értékeihez hasonló, de nyílvánvalóan a Lakanen-Erviö módszer használata miatt alacsonyabb eredményeket kaptunk.

\section{Összefoglalás}

Kutatásunkban arra kerestük a választ, hogy az antropogén tevékenységek milyen hatást gyakorolnak a városi talajokra. Sopron és Szombathely város területén és környékén összesen 192 ponton gyüjtöttünk talajmintákat 0-10 cm és 10-20 cmes mélységben. A kémiai és fizikai talajtulajdonságok laboratóriumi meghatározása után, az oldható toxikus elemek mennyiségének méréséhez (ICP-OES) LakanenErviö-féle kivonatot (LAKENEN \& ERVIÖ, 1971) készítettünk.

A terepi és a laboratóriumi mérési eredményeket térinformatikai módszerekkel dolgoztuk fel (DigiTerraMap), majd következtetéseket vontunk le a helyszíni adatok, a laboratóriumi értékek és a készített tematikus térképek alapján. A mérések során hat elemet $(\mathrm{Co}, \mathrm{Cd}, \mathrm{Ni}, \mathrm{Cu}, \mathrm{Zn}, \mathrm{Pb})$ emeltünk ki, melyek kiemelkedö fontosságúak a városi talajokban. A talajminták eredményeinek kiértékelését a Magyarországon hatályos rendeletek határértékei és a KÁDÁR (1998) által javasolt határértékek alapján végeztük.

A szombathelyi talajok kémhatása semleges $(\mathrm{pH}=6,9)$, és a toxikus elemek elöfordulása magasabb koncentrációban csak néhány esetben volt jellemző. A minták fele nem tartalmazott kalcium-karbonátot. A városközpont felé haladva folyamatosan nőtt a karbonáttartalom, mely erős összefüggést mutatott a kémhatással (felső rétegben: $\mathrm{R}^{2}=0,75$; alsó rétegben: $\mathrm{R}^{2}=0,78$ ). A talajok fizikai félesége mindkét rétegben agyagos vályog volt.

A nehézfémtartalom alapján jelentős eltérés nincs az egy ponton mért egymás feletti rétegek között. A felső rétegben több pont mutat szennyezettségi határértéket meghaladó értéket. Az alsó rétegben, ugyan kevesebb mintavételi ponton, de magasabbak, sőt bizonyos helyen kiugróak a mért nehézfém értékek.

A természetes háttérkoncentrációt nem haladta meg Cd-, Co- és a Ni-tartalom. A $\mathrm{Cu}$-tartalom több esetben nagyobb, mint a természetes háttérkoncentráció, de a szennyezettségi határértéket $\left(40 \mathrm{mg} \mathrm{Cu} \cdot \mathrm{kg}^{-1}\right)$ nem érte el. 
A forgalmas - elsősorban belvárosi - utak mellől gyüjtött talajok a folyamatos terhelés miatt ólommal szennyezettek. Ez a terhelés a külváros felé haladva mérséklödhet, csökkenhet az Pb-tartalom, de a külvárosi savanyú kémhatású területek felé haladva a kisebb forgalomból származó ólomterhelés is veszélyes lehet, az ólom mozgékonyságának növekedésével. Cinkre nézve $14 \mathrm{db}$ minta az első intézkedési határértéket, kettő pedig a $80 \mathrm{mg} \mathrm{Zn} \cdot \mathrm{kg}^{-1}$-ot is meghaladta; mely értékeket a Gyöngyös patak parti mintákban találtunk.

Összefoglalva úgy véljük, hogy a jövőben a patakparti minták további részletes vizsgálatára kell hangsúlyt fektetni. Ezen felül a városi növények elemzésére is sor kerülhet, mivel a patak mentén parkok, sétányok és pihenőövezetek vannak, tehát a talajszennyezés hatással lehet az emberi egészségre. Az összes elemre nézve a legmagasabb összterhelést a belvárosi parkok talajának két rétegében mértük. A levegőből származó szennyeződések megkötődnek a város zöldfelületein, és bemosódhatnak a parkosított patakpartok talajába.

Kutatásunkat a TÁMOP 4.2.1.B-09/1/KONV-2010-0006 projekt támogatta. Külön köszönet illeti Dr. Szücs Pétert, aki a Digiterra program használatában nyújtott segítséget és munkánkban hosszú éveken át közremüködött.

Kulcsszavak: városi talajok, nehézfémtartalom, feltalaj, területhasználat

\section{Irodalom}

10/2000. (VI. 2.) KöM-EüM-FVM-KHVM együttes rendelet a felszín alatti víz és a földtani közeg minőségi védelméhez szükséges határértékekröl.

6/2009. (IV. 14.) KvVM-EüM-FVM együttes rendelet a földtani közeg és a felszín alatti vízszennyezéssel szembeni védelméhez szükséges határértékekről és a szennyezések méréséröl.

ÁdÁm L., JuhÁsz Á., MARosi S., Mezösi G., Somogyi S. \& SZILÁRd J., 2010. Domborzat. In: Magyarország kistájainak katasztere. (Ed.: DövÉNYI Z.) MTA Földrajztudományi Kutatóintézet. Budapest.

Bellér P., 1997. Talajvizsgálati módszerek. Egyetemi jegyzet. Soproni Egyetem, Erdőmérnöki Kar, Termőhelyismerettani Tanszék. Sopron.

Bergbä̈K, B., JohANSSON, K. \& MoHLANDER, U., 2001. Urban Metal Flows - A Case Study of Stockholm. Review and Conclusions. Water Air Soil Pollut. 1. (3-4) 324.

Bidló, A., Horváth, A., KÁMÁn, O., NÉMETH, E., PÖDÖR, A. \& SzŰCs, P., 2012. Soil Investigation in cities of West Hungary. In: The Impact of Urbanization, Industrial, Agricultural and Forest Technologies on the Natural Environment. (Eds.: NEMÉNYI, M. \& HEIL, B.) 147-160. Nemzeti Tankönyvkiadó. Budapest.

BillwitZ, K. \& BREUSTE, J., 1980. Anthropogene Bodenveränderungen im Stadtgebiet von Halle/Saale. In Wiss. Zs. MLU, Math.-naturwiss. R. Halle. 14. (4) 25-43.

Blume, H. P., 1992. Handbuch des Bodenschutzes. Ecomed Verlag. Germany.

Blume, H. P. \& Hellriegel, T., 1981. Blei- und Cadmium-Status Berliner Böden. Z. Pflanzenernähr. Bodenkde. 144. 181-196. 
BockheiM, J. G., 1974. Nature and Properties of Highly Disturbed Urban Soils. Philadelphia. Pennsylvania. Div. S-5, Soil Science Society of America. Chicago.

BudAi T. \& KONRÁD GY., 2011. Magyarország földtana. Egyetemi jegyzet. Pécs.

Burghardt, W., 1994. Soils in urban and industrial environment. Plant Nutr. Soil Sci. 157. (3) 205-214.

Carre, F., Rusco, E., Tóth, G., Jones, A., Gardi, C. \& Stolbovoy, V., 2013. Soil sampling methodology. In: LUCAS Topsoil Survey methodology, data and results. (Eds.: Tóth, G., Jones, A. \& Montanarella, L.) 3-8. Luxembourg: Publications Office of the European Union, 2013 Ispra, Italy.

CRAUL, P. J., 1992. Urban soils (Applications and practices). John Wiley \& Sons Inc. New York.

CSATHÓ P., 1994. A környezet nehézfém szennyezettsége és az agrártermelés. Tematikus szakirodalmi szemle. MTA-TAKI. Akaprint. Budapest.

Entwistle, J. A., Abrahams, P. W. \& Dodgshon, R. A., 1998 Multi-element analysis of soils from Scottish historical sites. Interpreting land-use history trough the physical and geochemical analysis of soil. J. Archaeol. Sci. 25. 53-68.

FAO, 1990. Guidelines for soil description. 3rd Ed. Soil Resources, Management and Conservation Service, Land and Water Development Division. FAO. Rome.

FIEDLER, H. J., 1990. Bodennutzung und Bodenschutz: Jena. VEB Gustav Fischer. Verlag. Stuttgart.

Filep Gy., 1999. A talaj fizikai tulajdonságai. In: Talajtan (Eds.: STEFANOVITs P., FiLEP GY. \& FÜLEKY GY.) 131-190. Mezőgazda Kiadó. Budapest.

FÜGEDI U., HORVÁTH I. \& ÓDOR L., 2007. Geokémiai háttérértékek Magyarország hegyvidéki területein. Földtani Közlöny. 137. (1) 63-74.

FüLEKY GY., 1999. Növényi tápanyagok a talajban. In: Talajtan (Eds.: STEFANOVITs P., FILEP, GY. \& FÜLEKY GY.) 191-223. Mezőgazda Kiadó. Budapest.

FÜLÖP J., 1990. Magyarország geológiája - Paleozoikum I. Magyar Állami Földtani Intézet. Budapest.

GYÖRI D., 1958. Néhány talajtípus mikroelem készlete. Agrokémia és Talajtan 7. (2) 97-110.

Hiller, D. A. \& Meuser, H., 1998. Urbane Böden (Urban soils). Springer. Berlin.

Horváth A., Szücs P., Kámán O., Németh E. \& Bidló A., 2013a. Sopron város és környéke feltalajának vizsgálata. Tájökológiai Lapok. 11. (1) 125-134.

Horváth A., SzüCs P., KÁMÁN O., NÉMETH E. \& BIDLÓ A. 2013b. Talajtulajdonságok vizsgálata Szombathelyen. In: Talajvédelem 2013. Talajtani Vándorgyülés Különszám. (Eds.: Dobos E., Bertóti R. D. \& SzABónÉ K. G.) 237-248 Talajvédelmi Alapítvány. Miskolc.

HorvÁth, A., SzÜCS, P. \& BidLÓ, A., 2014. Soil condition and pollution in urban soils: evaluation of the soil quality in a Hungarian town. J. Soils Sediments. Springer. DOI 10.1007/s11368-014-0991-4.

IUSS Working Group WRB. 2007. World Reference Base for Soil Resources 2006. First update 2007. World Soil Resources Reports No. 103. FAO. Rome.

KÁDÁR I., 1993. Adatok a közlekedés, település és az ipar által okozott talajszennyezödés megítéléséhez. Növénytermelés. 42. 185-190.

KÁDÁR, I. 1995. A talaj - növény - állat - ember tápláléklánc szennyeződése kémiai elemekkel Magyarországon. KTM-MTA TAKI. Budapest. 
KÁDÁR, I. 1998. A szennyezett talajok vizsgálatáról. In: Kármentesítési Kézikönyv 2. (Szerk.: NÉMETH T.). Környezetvédelmi Minisztérium. Budapest.

KOVÁCS M. \& NYÁRI I., 1984. Budapesti közterületek talajainak nehézfémtartalma. Agrokémia és Talajtan. 33. (3-4) 501-510.

LAKANEN, E., ERVIÖ, R. (1971): A comparison of eight extractants for the determination of plant available micronutrients in soil. Acta Agr. Fenn. 123. 223-232. pp.

LEHMANN, A., 2007. Nature and significance of anthropogenic urbansoils. J. Soils Sediments 7. (4) 247-260

Li, X. D., LeE, S. L., Wong, S. C., Shi, W. Z. \& Thornton, I., 2004. The study of metal contamination in urban soils of Hong Kong using a GIS-based approach. Environ. Pollut. 129. 113-124.

McEldowney, S., Hardman, D. J. \& Waite, S., 1993. Treatment Technologies. In: Pollution Ecology and Biotreatment Technologies. (Eds.: McELdownEY, S., Hardman, J. \& Waite, S.) Longman. Singapore Publishers. Singapore.

Meuser, H., 2010. Contaminated Urban Soils. Springer Science-Business Media B.V.

Németh, E., Horváth, I. Bidló, A. \& Hofmann, T., 2014. Evaluating soil, grape and wine composition in the Sopron Wine Region, Hungary. Agrokémia és Talajtan. 63. (1) 165-174.

Norra, S. \& StÜBEn, D., 2003. Urban soils. J. Soils Sediments. 3. (4) 229-233.

NovÁK T. J., 2013. Talajtani praktikum. Meridián Alapítvány. Debrecen.

PUSKÁS I. \& FARSANG A., 2007. A városi talajok osztályozása és antropogén bélyegeinek meghatározása Szeged példáján. Tájökológiai Lapok 5. (2) 371-379.

PUSKÁS I., PRAZSÁK I., FARSANG A. \& MARÓY, P., 2008. Antropogén hatásra módosult fizikai, kémiai és biológiai tulajdonságok értékelése Szeged és környéke talajaiban. Agrokémia és Talajtan. 57. (2) 261-280.

RAJKAI K. \& TóTH G., 2010. Talajok. In: Magyarország Kistájainak Katasztere. (Ed.: DöVÉNYI Z.). MTA Földrajztudományi Kutatóintézet. Budapest.

Runge, M., 1975. Westberliner Böden anthropogener Litho- oder Pedogenese. Dissertation an der Technischen Universität. Berlin.

SÁNDOR, G. \& SzABÓ, GY., 2014. Influence of human activities on the soils of Debrecen, Hungary. Soil Science Annual. 65. (1) 2-9.

Scharenbroch, B. C., Lloyd, J. E. \& Johnson-Maynard, J. L., 2005. Distinguishing urban soils with physical, chemical, and biological properties. Pedobiologia. 49. 283-295.

SIMON L., VÁGVÖLGYI S. \& GYÖRI Z., 1999. Kadmiumakkumuláció napraforgóban. Agrokémia és Talajtan 48. (1-2) 99-110.

Simon L., PROKISCH J. \& GYÖRI Z. 2000. Szennyvíziszap komposzt hatása a kukorica nehézfém-akkumulációjára. Agrokémia és Talajtan. 49. (1-2) 247-256.

Stefanovits P., 1992. Talajtan. Mezőgazda Kiadó. Budapest.

SzABÓ GY., 1996. Nehézfémek a talajban. Földrajzi Közlemények CXX. (XLIV.). 4. 253-266.

SzABOLCS I., 1966. A genetikus üzemi talajtérképezés módszerkönyve. Országos Mezőgazdasági Minőségvizsgáló Intézet. Budapest.

SzEGEDI S., 1999a. Közlekedési eredetű nehézfémek Debrecen talajaiban és növényzetében, ennek talajtani összefüggései és városökológiai hatásai. Doktori értekezés. Kossuth Lajos Tudományegyetem. Debrecen. 
SzEGEDI S., 1999b. Debrecen nehézfém-szennyezettsége. Magyar Tudomány CVI/XLVI. k. 10. 1192-1200.

SZOLNOKI, Zs., FARSANG, A. \& PUSKÁs, I., 2013. Cumulative impacts of human activities on urban garden soils: Origin and accumulation of metals. Environ. Pollut. 177. 106-115.

THORTON, I., 1991. Metal contamination of soils in urban areas. In: Soils in the Urban Environment. (Eds.: BULlOCK, P. \& GREGORY, P. J.). Blackwell. Oxford.

То́тн I., 2011. Sopron város története. Kutatási összefoglaló. Soproni Múzeum. Sopron.

UREN, N. C., 2012. Cobalt and Manganese. In: Heavy Metals in Soils: Trace Metals and Metalloids in Soils and their Bioavailability. (Ed.: AllowAY, B. J.) Springer. Glasgow.

VARGa, G., Konkoly-Gyúró, É., Kovács, G., Schmidt, G., Radó, D., BARANYI, K., Czimber, K., Boros, G., HéJu, B., Krassay, L., Rácz, I., Szemerédy, M. \& VARGA, T., 1999. Information system describing the condition of urban trees and forests. Urban Greening and Landscape Architecture. Koppenhaga.

ZöTTL, H. W., 1987. Responses of forest decline to experimental fertilization. In: Effects of Atmospheric Pollutants on Forests, Wetlands and Agri-cultural Ecosystems. (Eds.: Hutchinson, T. C. \& MeEma, K. M.) Ecol. Sci. 16. 255-265.

Érkezett: 2015. február 9. 


\title{
Heavy metal investigation of urban soils in the Transdanubian region
}

\author{
A. HORVÁTH and A. BIDLÓ
}

University of West Hungary, Faculty of Forestry, Sopron

\begin{abstract}
Summary
The investigation was aimed at determining the impact of human activities on urban soils. A total of 192 soil samples were collected at depths of $0-10$ and $10-20 \mathrm{~cm}$ at locations in the towns of Sopron and Szombathely and in neighbouring areas. After the analysis of chemical and physical properties, the heavy metal concentrations were measured using ICP-OES according to the method of Lakanen and Erviö. The field and laboratory data were processed using a GIS system (DigiTerraMap), which provided a useful basis for research. In the course of the measurements six elements were selected $(\mathrm{Co}, \mathrm{Cd}, \mathrm{Ni}, \mathrm{Cu}, \mathrm{Zn}, \mathrm{Pb})$, which are prominent in urban soils. The results were evaluated on the basis of the limit values in force in Hungary and on the limits suggested by KÁDÁR (1998).

The $\mathrm{pH}$ of urban soils in Szombathely was generally neutral $(\mathrm{pH}=6.9)$ and the occurrence of toxic elements in high concentrations was not typical. Half the samples contained no calcium carbonate. The $\mathrm{CaCO}_{3}$ content increased from the suburbs towards the city centre, and this exhibited a strong correlation with the soil $\mathrm{pH}$ (topsoil $\mathrm{R}^{2}$ $=0.75$, subsoil $\mathrm{R}^{2}=0.78$ ). In both soil layers the texture was clayey loam. There were no significant differences between the data recorded for the different soil layers at each sampling point. Values above the pollution limit were observed at several sampling points in the $0-10 \mathrm{~cm}$ layer, but fewer cases of higher or outstanding values were recorded in the lower layer. The $\mathrm{Cd}$, $\mathrm{Co}$ and $\mathrm{Ni}$ values were lower than the suggested natural background limits. Although the copper values exceeded the natural background concentrations in several cases, the pollution limit $\left(40 \mathrm{mg} \mathrm{Cu} \cdot \mathrm{kg}^{-1}\right)$ was not reached. Samples taken alongside busy roads, especially in the city centre, were contaminated with lead due to the continuous traffic. The $\mathrm{Pb}$ concentration decreased slightly towards the suburban areas of the city. Nevertheless, as the suburban soils were more acidic, even the lower $\mathrm{Pb}$ pollution caused by the lower traffic level could be dangerous because of the increase in $\mathrm{Pb}$ mobility. In 14 samples the zinc level exceeded the intervention limit, and in two of these, both taken from the bank of the Gyöngyös stream, the concentration was higher than $80 \mathrm{mg} \mathrm{Zn} \cdot \mathrm{kg}^{-1}$.

In summary, future studies should focus on the detailed examination of soil samples taken from the banks of the stream. It would also be worth analysing the urban plants growing in this habitat, since parks, walkways and recreation areas have been formed along the stream, so soil pollution could affect human health. For all the heavy metals, the highest pollution levels in both layers were recorded in the soils of green areas. Airborne pollutants are absorbed on the surface of the vegetation in green areas of the city or are washed into the soils of the parks lining the stream as, unlike concreted surfaces, these locations facilitate the infiltration of heavy metals.

Table 1. Recommended limit values (A: natural background concentration, B: contamination limit, $\mathrm{C}$ : intervention limit value) and comparison of individual elements, $\mathrm{n}$ :
\end{abstract}


number of samples. (1) Depth. (2) Statistical characteristic. a) Mean, b) Standard deviation. Note: In the case of $\mathrm{Cd}$, no limit was given in the manual, so those given in the joint ministerial regulations on limit values required for protection against the contamination of geological materials and subsurface waters (6/2009. (IV.14.) KvVM-EüMFVM) and on the limit values required to protect the quality of geological materials (10/2000. (IV. 2.) KöM-EüM-FVM-KHVM) were taken into consideration.

Figure 1. Location of sampling points on the sample areas.

Figure 2. Distribution of sampling points according to land use categories.

Figure 3. $\mathrm{Pb}$ content of the lower soil layer in Szombathely soils as a function of the lead content of the upper layer.

Figure 4. Lead content at soil depths of 0-10 cm and 10-20 cm (based on KÁDÁR, 1998). 